\title{
Legitimacy in Afghanistan: A Critical Analysis of Historical and Contemporary Sources of Authority
}

\author{
Mujib Abid \\ University of Sydney, Sydney, Australia
}

\begin{abstract}
Sources of legitimacy in Afghanistan are diverse, competing and contested, with traditional roots. Historical and contemporary observation suggests a major rift between a "sedentary" and a "desert" populace - that is urban dwellers and rural inhabitants. Tribal patronage, with its lashkars and militias, has traditionally been central to legitimacy of any claim to the throne, and lack of it has doomed any such aspiration. This dynamic shifted in the 19th century as the state attempted to consolidate its rule by relying on standing armies independent of tribal forces. While the Kabul-based dynasties generally upheld this new power structure well into late 20th century, with a few relapses, the persisting tensions ultimately led to an acute conflict. The Mujahidin insurgency of the 1980s and early 1990s was a manifestation of this competition. Afghan Jihad here is intentionally examined as a protracted conflict independent of its Western influence and backing and as it pertained to pillars of power and legitimacy of authority in the Afghan context.
\end{abstract}

Keywords: legitimacy, Afghanistan, Afghan war, tribalism, Mujahidin, history

\section{Introduction}

In 1992, whilst the various Mujahidin factions had other non-US patrons, albeit less generous and increasingly selective, the People's Democratic Party of Afghanistan (PDPA) government in Kabul was completely abandoned by the disintegrating Soviet Union (Rubin 1995, p. 106). Eleven weeks after the announcement that his government would receive no further direct aid from the USSR, President Mohammad Najibullah appeared on national television, reading a resignation speech that was written by the UN envoy Benon Sevan, to take effect once an "interim government" was established by the UN. This officially closed the chapter on Marxist-Leninist socialism in Afghanistan.

Because the Jihad movement had empowered historically disempowered social groups, it was in the interest of the competing Mujahidin factions to "take power before they could legitimize their right to it" (Barfield, 2010 p. 251). Historically in Afghanistan, power had been secured through appeals to royal political legitimacy coupled with foreign subsidies, which time and again ended civil wars and established order. In Afghanistan of 1992, the Soviet Union had finally closed its book on the Great Game in Afghanistan, and the United States therefore no longer had any interest in the otherwise strategically irrelevant and resource-poor country on the verge of collapse (Barfield, 2010, p. 251). Worst, the "victorious" Mujahidin had no agreement on what a future government should look like, or who should lead it - as long as it did not involve Zahir Shah. The stopgap solution of returning Zahir Shah to power, which would have enabled the traditional appeal to 
royal political legitimacy, had been ruled out, and insufficient foreign aid was going to be forthcoming for rival groups within Afghanistan. The result was a free-for-all mad scramble for power.

Mujahidin, in their quest to seize control of Afghanistan, therefore faced a significant challenge in establishing legitimacy, understood in the Weberian sense as an acceptable system of "imperative co-ordination" (Weber, 1947a, p. 324). Lack of legitimacy proved to be the main hindrance to delivering a peaceful end to the Afghan-Soviet war; in fact, it led directly to Afghanistan's slip into the chaotic inter-factional "civil war", which had the unintended consequence of largely nullifying and delegitimising the "cause of Jihad". But while political disagreements among rival Mujahidin groups only resulted in open collision at the outset of the Soviet withdrawal from Afghanistan, this crisis had been in the making for an extended period of time.

To fully grasp the Afghan conflict, now in its fifth decade, it is crucial to highlight the contextually specific manifestation of political legitimacy and authority to rule both in its historical as well as contemporary settings. Deep links between the two settings are present, with significant implications for post-2001 Afghanistan. To that end, this paper is divided into two parts. The first section examines the historical evolution of the notion of legitimacy in Afghanistan by highlight shifting sources and significant tensions between competing sources of authority. The second part of the paper utilises the Khaldunian "civilization theory" to examine Mujahidin, insurgent factions that resisted the Soviet occupation of Afghanistan, and the sources of their authority (Khaldun, 1969).

\section{Historical Sources of Legitimacy}

Sources of legitimacy have evolved during the modern history of Afghanistan, gradually shifting away from the principal source of legitimacy being decentralized and tribally dominated shared use of coercive force, towards a complete state monopoly on the use of violence. Yet this process has historically faced stiff opposition, mainly from the rural population, which can be characterized as a "desert civilisation". Ibn Khaldun described desert civilization as communal groups living in remote and rugged environments based on subsistence agricultural economies that uphold tribal laws of kinship, revenge, egalitarianism, and honor.

The shift towards centralization of sources of legitimacy into the hands of the Afghan state was first driven by colonial contact. Tales of the First Anglo-Afghan War (1839-1842) frequently highlight the "valour" that jezail-wielding Afghan tribal warriors showed in the massacring of the 16,000-strong British "Army of the Indus" in that dreadful winter retreat from Kabul (Dylrample, 2013). ${ }^{1}$ It is exaggerated by Afghan nationalists, forever imprinted in the memories of common Afghans, and taught at military academies to demonstrate the monumental British military disaster. On a less dramatic note, however, contact with the British East India Company led to a complete overhaul of the role of army in the tribal society, underlining the importance of a standing army (Barfield, 2004, p. 273). ${ }^{2}$ Afghan armed forces, on which the invading army relied for survival, was centralized and brought under direct state control, a move that hit the core of any previously held notion of legitimacy: lashkars, or tribal militias winning wars (Barfield, 2004, p. 275). In the decades that followed the

\footnotetext{
${ }^{1}$ For a complete narrative of the 18th century power struggles in Afghanistan and the first encounter of Afghanistan with the colonial British India see Dylrample (2013).

2 British India introduced money - silver rupees and letters of credit - in an important "connexion" to move towards legal-rational authority which transformed Afghanistan's feudal subsistence-based economy. Internal revenue, the British claimed, rose from 225,000 to 900,000 rupees by "modernising" the taxation system. In addition, international fruit merchants for the first time were allowed entry to do business with local Afghan producers.
} 
First Anglo-Afghan war, Afghan Amirs realized the importance and key role of a standing army for protection, and indeed survival. Under these influences, the Afghan army was therefore increasingly centralized and brought under direct state control, a move that devastated the core standard bearers of traditional notions of legitimacy: the lashkars, or tribal militias (Barfield, 2004, p. 275).

This acute shift is nowhere more visible thanwhen comparing the two reigns of Amir Dost Muhammad Khan (1826-1839 and 1843-1863), pre and post-war. During his first reign, the Amir could barely control the Kabul to Kandahar region. He was easily deposed from his first reign and routed by British troops at the outset of the war, spent much of the war on the run or in captivity and regained power through the agency of the British after their abandonment of Afghanistan. Resistance to British occupation was decentralized and enacted through various tribal militias. During the Amir's second reign, in contrast, British-introduced reforms, including keeping a strong standing army, were utilized to consolidate his rule in almost all of present day Afghanistan and he pushed state revenues to seven million rupees (Yapp, 1964, p. 381). The newfound stability and source of legitimacy came as a result of a close relationship with the British East India Company. ${ }^{3}$ His successor Amir Sher Ali Khan further expanded these state structures and consolidated his power by such means as the enhancement of the standing army and establishing the first Afghan weapons factory in Kabul, under the tutelage of British Raj (Tanner, 2002, p. 203).

In this sense, contact with the British colonizers enabled the fundamental alteration of the state-society relationship in Afghanistan by ending the former's dependence on the latter's military might. For the first time state was independent of the rural but powerful tribes of the "periphery", and hence did not have to seek legitimacy in winning wars or share authority with the tribes. Legitimacy now came from the army, "modernized" and empowered by British subsidy, with predictable impacts upon tribal leaders and militias, who found their traditional source of legitimacy under attack. In subsequent decades, many tribal uprisings were violently crushed, with hundreds of revolting Ghilzai tribes and Hazara communities, for example, coercively resettled (Mousavi, 1998, pp. 129-131). This trend of state military dominance over tribal power went on until the 1928 nation-wide uprising that toppled King Amanullah Khan, where for a brief period "desert civilization" regained its historical dominance (Barfield, 2012a, p. 124). ${ }^{4}$ To counter the insurrection, Nadir Shah, patriarch of the Musahiban Dynasty and Amanullah's war minister, would do the impossible; in a sign and reaffirmation of the extreme makeover of the very fabric of the Afghan society, Nadir Shah won over his historical rivals, the Ghilzais of the Afghan-India borderlands, who helped him regain the throne from the "Bandit King"Bacha-i Saqau, or "son of the water carrier" (Culture and Geographic Research, 2008). Though Nadir Shah was more cautious in his monopolization of the sources of legitimacy for the exercise of power in Afghan society than some of his predecessors, the principal source of legitimacy within Afghan society continued to reside with the standing army, until the Saur Revolution.

The combination of the decline of the army under PDPA government and the growing power of Mujahidin groups during the 1980s led to a highly significant reversal of the one and a half-century long process of consolidating legitimacy that emanates from the state apparatus. The Afghan Jihad had once again placed countryside tribal communities and militias in the forefront of Afghan society as a resurrected power elite,

\footnotetext{
${ }^{3}$ Culcutta, for example, rewarded the Amir handsomely-2.6 million rupees - to defend Herat and for not aiding the 1857 Indian Mutiny.

${ }^{4}$ Barfield compares Kalakani to Mullah Omar, especially unique are their circumstances of coming to power-in both periods Afghanistan was isolated and subsidies to state authority had stopped (Barfield, 2004, p. 124).
} 
evident in their makeup and collective background (Mahapatra, 1997, pp. 135-138). This shift, however, resulted in unprecedented chaos and bloodshed, and a complete breakdown of Afghan society (Roy, 1989, pp. $73-75)^{5}$

\section{The Two Civilizations: Ibn Khaldun and Afghanistan}

Eighty five percent rural, and containing only small, isolated pockets of urban settlement, "Afghanistan remains a place that Ibn Khaldun, the father of social sciences, could easily recognize"(Barfield, 2010, p. 65). Tamim Ansary (2012) has utilized a Khaldunian approach to explain the Afghan conflict. That seven centuries later, Ibn Khaldun' sal-Muqaddimah, or Introduction, is still relevant should come as no surprise, least of all in Afghanistan where Afghan tribalism remains intact, sharing traits with ibn Khaldun's desert civilizations: camel-riding Bedouins, Turkic steppe nomads, and Kurdish mountain villagers. ${ }^{6}$ The medieval Arab historian described a long-standing bipolar division between what he termed "desert civilizations" and "sedentary civilizations" (Barfield, 2010, p. 56). The former is described as communal groups living in remote and rugged environments based on subsistence agricultural economies that uphold tribal laws of kinship, revenge, egalitarianism, and honor (Barfield, 2010, p. 56). Asabiyya, or group feeling - also interpreted as "clanism", or in modern terms ethnic nationalism — was a term coined by Ibn Khaldun to describe bonds of cohesion among communities, which he claimed was strongest in desert civilizations and fades as communities settle (Khaldun, 1969, pp. 97-98). The latter, relying on surplus agricultural production, are human societies with complex mercantile systems that are formed of densely populated urban areas (Khaldun, 1969, p. 122). Historically, as in the riverbed civilizations of Euphrates and Tigris, Ganges, Nile, and the Yellow River, sedentary civilizations were organized on residency, rather than kinship, and structured on class and occupational rank and file (Khaldun, 1969, p. 122). The urbanites considered themselves cultured and superior, and controlled the flow of commercial goods.

The two civilizations often are in a position of constant interdependency, with migrations from the periphery into the cities and the city dwellers relying on the labor and manpower of the healthier periphery (Barfield, 2010, p. 57). Ibn Khaldun (1969) noted:

While (the Bedouins) need the cities for their necessities of life, the urban population needs (the Bedouins) [only] for conveniences and luxuries... They must be active on the behalf of their interests and obey them whenever (the cities) ask and demand obedience from them. (p. 122)

Ibn Khaldun's definition of the relationship between historic desert and sedentary civilizations still holds considerable salience when seeking to understand late 20th century politics and society in Afghanistan. There is a persistent and profound division between rural and urban societies within Afghanistan, which arguably surpasses the oft-cited differences in ethnicity and language. Generally, if any cultural orthodoxy or orthopraxy were embraced within urban centres, people within the mountainous margins would endorse the opposite (Canfield, 1973). During the Soviet War in Afghanistan, the Kabul-based PDPA government was larger, had centralized power, and kept control of key resources, in line with the medieval Arab's definition of sedentary

\footnotetext{
${ }^{5}$ While initially majority of Jihadi elite went powerless as Taliban finally consolidated power in 1996, the groups that allied themselves with the American campaign in Afghanistan made a comeback and have ever since secured a dominant political presence for themselves.

6 The Muqaddimah is written in 1375 , as part of a planned 10 book series of world history by the father of social sciences Ibn Khaldun.
} 
civilization, whereas the various Mujahidin groups relied on divinity, kinship, and assabiya, or group feeling, as a source and enforcer of legitimacy. The marginal population remained estranged from politics; in fact, "as its [Afghanistan] passive inhabitants" they were not concerned with the Kabul-based centre of power "and hence concepts of patriotism, citizenship, or indeed any sense of political obligation to the state was almost entirely absent" (Barfield, 2010, p. 63).

Despite the PDPA government, or the centre, having a relatively dominant monopoly of power, because it looked at the people of the "hinterlands [as] more barbarian than civilized", and ignored or feared them, the urban and rural power dwellers found themselves in a competition for leverage (Barfield, 2010, p. 65). Whatever authority the state had consolidated in the decades preceding the communist revolution of 1978, it lost in the next decade. These tensions, always there but perhaps hidden by a traditional monarch, between the "sedentary" (city) and the "desert" (countryside) civilizations collided in the guise of Jihad. Although an argument could be made about the initial PDPA regime (the short lived Khalqi regime of Taraki-Amin which was removed upon the Soviet Invasion) to be framed as a takeover of power by the "desert civilization" while consenting to receive the urban elite, the most radical communist reforms coupled with some of the most gruesome atrocities committed by the state at the time propelled the nationwide uprising that would keep the lines from blurring (Bellamy, 2012b, pp. 175-190). ${ }^{7}$ Besides, despite Khalq's predominantly rural Pashtun leadership and membership, it was a radical communist group that attracted the educated and only with such family backgrounds, still operating in the context of urban Kabul political environment (Rasanayagam, 2003, p. 60).

Amid this divisive struggle for power, to ibn Khaldun the only way Bedouins (used synonymously with desert civilization) can "acquire royal authority [legitimacy to rule] is by using some religious coloring, such as prophethood, or sainthood, or some great religious event in general" (Khaldun, 1969, p. 120). All Mujahidin groups, as was described in the previous chapter, claimed divinely sanctioned legitimacy, to restore the sovereignty of Allah and win over Afghanistan's independence from "infidel Soviets". Of the seven major Mujahidin factions, all but one had the word "Islamic" in their names, four subscribed to the "political Islam" (making the Islamic Unity of Afghanistan Mujahidin - the 1985 organization that nominally united Jihad) and three factions were considered "traditional-nationalists" (Amin, 1984, p. 381). Another eight Tehran-based Shia parties also claimed religious recognition. This, Ibn Khaldun claimed in the context of the Bedouins is due to their "savagery" - unwillingness to subordinate to each other (Khaldun, 1969, p. 120). To rid them of the "haughtiness and jealousy", a prophet or saint is required to call for the fulfilment of the command of God (Khaldun, 1969, p. 120). Amir of Mujahidin, the closest to a religiously sanctioned non-Caliph ruler, called for Jihad in 1975. On a different note, Mecca — the holiest site for all Muslims—remained a crucial strategic place of meeting for the disputing Mujahidin factions throughout the war and beyond-although rarely were agreements honored. ${ }^{8}$

Similar to Amartya Sen's (2006) observation that "gullible" people show conformism in adopting belligerent singular-identities without critical thinking, ibn Khaldun states: "besides, no people are as quick to

\footnotetext{
${ }^{7}$ Human rights violations and atrocities committed by the PDPA-regime against civilians and Mujahidin, including executions, mass graves, indiscriminate bombing, and imprisonments, are widespread. For a full account of communist atrocities, both preand post Soviet occupation Afghanistan (Bellamy, 2012b, pp. 275-290).

8 Although Saudis kept a close contact with Sayaf, they remained key financer and ally to all Sunni Mujahidin factions. Rabbani went on a fund raising campaign in the Kingdom when the 1975, Hekmatyar-planned disastrous coup went underway. Throughout the Jihad, Mujahidin elite met there on numerous occasions in futile attempts to unify under one leader.
} 
accept (religious) truth and right guidance" for they have not been corrupted by the indulgences and debauchery - only available in the surplus based economies of the sedentary civilizations - of the cities (Khaldun, 1969, p. 120). As such, recruitment of young men without any prospects in the bustling refugee camps of Peshawar came through "sermons" by notable Mujahidin leaders. Hekmatyar, for example, author of around 90 books on Islamic philosophy and an acclaimed orator gave long, theological speeches where he called Afghan communists murtad, or filth, at the service ofthe infidel lashkar of Soviet Army.

In conclusion, by the end of the Soviet occupation of Afghanistan, there was a complete shift in the social fabric and political class of Afghanistan - the periphery significantly outshone the center. The Taliban, which grew out of and in retaliation to the Mujahidin, took their radicalism to new extremes, readily imprisoning and executing those with non-village identities and instituting significant restrictions upon women and minorities. Since the 2001 American-led Western occupation of Afghanistan, any attempt to turn the tide, or at least maintain a reasonable balance, have been marred by Western-backed powerful warlords and Jihadi figures with rural support bases resisting reform (Rubin, 2007, pp. 266-269).

\section{References}

Amin, T. (1984). Afghan resistance: Past, present, and future. Asian Survey, 24(4), 373-399.

Barfield, T. J. (June 2004). Problems in establishing legitimacy in Afghanistan. Iranian Studies, 37(2), 263-293.

Barfield, T. (2010). Afghanistan: A cultural and political history. New Jersey: Princeton University Press.

Barfield, T. J. (April 2012). Afghans look at 2014. Current History.

Bellamy, A. J. (2012). Massacres and morality: Mass atrocitites in an age of civilian immunity. London: Oxford University Press. Canfield. (1973). cited in Barfield, Afghanistan: A cultural and political history. New Jersey: Princeton University Press.

Culture and Geographic Research. (2008). Tribal Analysis Center.

Dylrample, W. (2013). Return of a king. USA: Knopf Doubleday Publishing Group.

Khaldun, I. (1969). The Muqaddimah. Franz Rosenthal (Trans.). New Jersey: Princeton University Press.

Mahapatra, C. (Spring, 1997). The Afghan turmoil: Problems and prospects. India International Centre Quarterly, 24(1).

Mousavi, S. A. (1998). The Hazaras of Afghanistan: An historical, cultural, economic and political study. UK: Curzon Press.

Rasanayagam, A. (2003). Afghanistan: A modern history. London: I. B. Tauris.

Roy, O. (October, 1989). Afghanistan: Back to tribalism or on to Lebanon? Third World Quarterly, 11(4), 73-75.

Rubin, B. R. (1995). The search for peace in Afghanistan: From buffer state to failed state. London: Yale University Press.

Rubin, B. R. (January-February, 2007). Saving Afghanistan. Foreign Affairs, 86(1), 57-79.

Tanner, S. (2002). Afghanistan: A military history from Alexander the great to the fall of the Taliban. Cambridge: DA Capo Press. Weber, M.(1947a). The Theory of social and economic organization (Trans. by A. M. Henderson \& T. Parsons). New York: The Free Press.

Weber, M. (1947b). The types of authority and imperative co-ordination. In A. M. Henderson \& T. Parsons (Trans.), Max Weber: The theory of social and economic organization. Glencoe, IL: Free Press.

Yapp, M. (1964). The revolutions of 1841-1842 in Afghanistan. School of Oriental and African Studies, 27(2), 333-381. 